\title{
Politics of Aesthetics and the Neo-Avant-Garde in Brazil
}

\author{
Marina Corrêa \\ University of Vienna, Vienna, Austria \\ Email: marina.correa@univie.ac.at
}

How to cite this paper: Corrêa, M. (2017) Politics of Aesthetics and the Neo-AvantGarde in Brazil. Open Access Library Journal, 4: e3155.

http://dx.doi.org/10.4236/oalib.1103155

Received: December 8, 2016

Accepted: January 13, 2017

Published: January 16, 2017

Copyright (@) 2017 by author and Open Access Library Inc.

This work is licensed under the Creative Commons Attribution International License (CC BY 4.0).

http://creativecommons.org/licenses/by/4.0/

\begin{abstract}
The discussion of the aesthetics of the avant-gardes needs to be considered as a global issue, even though its representation differs with each country of origin. This paper will discuss the methods of representation employed by two diametrically opposed artists, whose roots go back to the Brazilian neo-avantgarde movement: Eduardo Kac and André Vallias. This analysis of the avantgardes within the aesthetic of Modernity is based on Jacques Rancière's "régimes esthétiques", his idea of the "partage du sensible", and on the combination of his concepts of "mésentente et malentendu". In particular, we will address one specific question related to poetry since the beginning of the Modernity: how does post-neo-avant-garde poetry transfer subjectivity from the poem's immanence to the reader's/viewer's perception and inter-activity?
\end{abstract}

\section{Subject Areas}

Literature, Literary Theory

\section{Keywords}

Modern Literature, Politics of Aesthetics, Regimes Esthetiques, Neo-Avant-Garde, Jacques Rancière, Eduardo Kac, André Vallias

\section{Introduction}

The discussion of the aesthetics of the avant-gardes as predecessors of inter-media and digital arts always comes with the search for identity related to the countries of origin of its representatives, as if the cultural roots determined an artist's production-if in a global context. The nearly antagonistic unity of this assertion induces a reading of Modernity which in Jacques Rancière's [1] terms combines aesthetic regimes (global) with the politics of aesthetics (local):

La notion de modernité esthétique recouvre, sans lui donner aucun concept, la singularité d'un régime particulier des arts, c'est a dire d'un type spécifique de 
lien entre des modes de production d'œuvres ou de pratiques, de formes de visibilité de ces pratiques et de modes de conceptualisation des unes et des autres (Jacques Rancière, Le Partage, pp. 26-27).

At a later time, Rancière [2] reformulates this notion of aesthetic practices within Modernity by including specific means identified as given for interpreting post-modern poetry, such as those discussed here:

Le régime esthétique des arts, qui est le vrai nom de ce que beaucoup nomment modernité, noue des pratiques, des modes d'interprétation, des dispositifs institutionnels autour d'une idée de l'œuvre comme effectuation directe de la pensée dans les formes sensibles, non médiatisée par les modes et les règles de la représentation, c'est-à-dire, en dernière instance, qu'elle donne aux entités spécifiques de l'art un statut ontologique particulier et pose les questions de la politique à partir de ce statut (Jacques Rancière, "Le Partage/Le Fabrique", s.p.).

While "le régime esthétique des arts" is thus equated to Modernity itself, Rancière [2] on the other hand places the politics of aesthetics ("la politiques-pecifique du régime des arts") within the "partage du sensible": it is thus taken to take effect through the "régime esthétique des arts", enacting this ontological distribution of combining production (intelligentsia) and reception (passive absorption of arts)-as he points out referring to Schiller's “Über die aesthetische Erziehung des Menschen" in "activité de la pensée contre passivité de la matière sensible", placing his concept into "un état de double annulation où activité de pensée et réceptivité sensible deviennent une seule réalité, constituent comme une nouvelle région de l'être-celle de l'apparence et du jeu libres" (apud Rancière, "Le Partage/Le Fabrique", s.p.).

The aesthetics of Eduardo Kac and André Vallias should therefore be read as specific representations of a local production (i.e. Rancière's "politique specifique du régime des arts") within the context of a global "regime esthétique des arts"; but I also relate them to an older concept of modernity: In the 1940s, José Ortega y Gasset [3] focussed on a specific rupture of the inter-subjective relation between the artist and their reception, on the effects of this rupture in terms of the public opting for a sort of "sociological point of view" as the key feature of Modernity. The work of art ceases to offer an identification surface to the reader; music is not anymore created to evoke facile emotions; the arts provide neither identification nor pleasure as immediate effects for their perception anymore. Although his essay is deliberately unfair by separating the masses from a given minority capable of perceiving the essential meaning of arts, "the new art obviously addresses itself not to everybody, as did Romanticism, but to a specially gifted minority. Hence it arouses the indignation in the masses (José Ortega y Gasset, The Dehumanization, p. 11). This gesture of isolating the new aesthetic production by means of its effects on the reception matches the analysis we are proposing here. To under appreciate the masses because of their taste and to thereby categorize modern art as unpopular (in opposite to Romanticism) is Ortega y Gasset's sarcastic way to determine his concept of a thin line in Modernity, which begins with new forms of aesthetic production that go hand in hand 
with the "dehumanization of art":

$[\ldots]$ the new sensibility represents the generic fact and the source, as it were, from which the former spring. This sensibility is worthwhile to define. And when we seek to ascertain the most general and most characteristic feature of modern artistic production, we come upon the tendency to dehumanize art (Ortega y Gasset, Dehumanization, p. 18-19).

From today's perspective, we can easily apply Gasset's "unpopularity" of modern aesthetics within a society dominated by the mass-media such as in Brazil. It is these mass-media that post-avant-garde production will compete against or also play along with-sometimes it is through telecommunication that the artist manages to express his parody on and through that medium.

André Vallias [4] and Eduardo Kac [5] grew up in the Brazil of the 1960s, the former in São Paulo, the latter in Rio de Janeiro. The neo-avant-gardes had then become popular through the tropicália movement expressed in the plastic arts, as exemplified by the work of Hélio Oiticica, as well as music-ranging from contemporary classical music to pop music-(cf. Charles Perrone [6] "Versatile Vanguard", pp. 75-78) and concrete poetry turned into an international movement. The substantial exchanges between its key figures, with a considerable number of relevant exhibitions by the end of the 1960s and the releases of anthologies at the beginning of the 1970s, are today considered historical keys for the understanding of the "politique specifique" within the regime of the arts. André Vallias considers these key figures as his predecessors; his earliest works were created with serigraphy alluding to concrete poetry, and throughout his career he would honor his precursors, creating, in parallel to his digital works, concrete poems (all published on his blog), such as the distich "ameríndiol oudeixe- $o$ " (Amerindian/or leave it, 2014). In this concrete poem, Vallias paraphrases the slogan used during the dictatorship, "Brasil, ame-o ou deixe-o" (Brazil, love it or leave it), combining it with the word "Amerindian" that refers to the most persecuted group in Brazil today: the endangered ethnic minority that faced the existential threat of extinction due to, among others, the rapid expansion of the agro-industry. Continuing the idea of Décio Pignatari's [7] affirmation on concrete poetry of "the poet as a designer of the language" (Augusto de Campos et al, Teoria, p. 220), André Vallias combines media- slogans and forces the joined words to be anagrammatic by approximating "amor" and "amer" to the same semantic field of "ame- $o$ ", hypostatically (mis) understood through the familiarity of the known slogan.

Like André Vallias, Eduardo Kac is also a representative of the generation of artists born between 1955 and 1962, who were seeking new forms of expression and who tried to stir up the Brazilians from the long period of silent oppression suffered during the dictatorship. Kac participated in the exhibition Como Vai Você, Geração 80? (How are you doing, generation of the 80s?) in Parque Lage, Rio de Janeiro. It was at that time that he carried out the Cyborg project (1984), followed shortly thereafter by the Ornitorrinco (platypus) project (1986); these are both experiences with telepresence (robots) interacting with the public. In 
the 1990s, Johanna Drucker [8] remarked about these creations, "In various recent pieces, Kac has been exploring the possibilities of having human subjects project their wills and enact their desires as they interact through wireless and fully mobile robotic objects." (Johanna Drucker, Eduardo Kac, p. 19) Kac then left Brazil for good and settled in the USA, where he lives to date.

These two artists thus embody very different responses to the Brazilian neo-avant-gardes of the 1950s that cut all heritage ties to any specific aesthetic language: Vallias upholds the concretist's concept of adapting inter-media structures, employing updated digital media and translation concepts of his own making; he explicitly refers to the trio Augusto de Campos, Haroldo de Campos and Décio Pignatari (internationally considered, with Eugen Gomringer, as the fathers of concrete poetry) as his predecessors. Kac, on the other hand, negates the influences of concrete poetry und employs a different kind of textual hybridity, following concepts of visual poetry and works such as those of the Brazilian painter Abraham Palatnik [9], a main national representative of kinetic art, whose experimental work with kinds of "light" (cf. Mário Pedrosa, "The Chromatic Plastic", s.p.), has probably inspired Kac's research on visual effects obtainable with the aid of new technology. At the same time, both of them exemplify a generation that is considered, in its poetry making and in its radicalizing of Ortega y Gasset's idea of modernity, a descendant of the neo- avant-gardes of the 1950s.

But are these considerations, which would lead us toward an incidental canonization-along Harold Bloom's idea of "anxiety of influence"-acceptable? Even if we were to invert the values considered, such as suggested by William Marx [10] with his concept of "arrière-garde", where he identifies within the neo- avant-garde a perfect inspiring source for the historical avant-garde (William arx, ed., Les arrière-gardes, pp. 8-9): Does this amount to anything more than just re-assessing the status of influence and being influenced? Would it not be rather much more pertinent and interesting instead to re-think Modernity through aesthetic representations like those by Vallias and Kac and to consider categories other than those of aesthetic heritage?

These questions become less pertinent when considered through Jacques Rancière's concept of Modernity. The politics of aesthetics of the avant-gardes in Rancière's Partage du Sensible as addressed above share the same fundament with all aesthetic thinking within Modernity. Jacques Rancière's "régimes esthétiques", his "partage du sensible", as well as the combination of his concepts of "mésentente" and "malentendu" (discussed below) lead us to question the aesthetic position of these two artists in a society which encounters both late industrialization and post-industrial effects.

In the Brazil of the last decades of the $20^{\text {th }}$ century, poverty and illiteracy coexist with the development of high technology and industrial investments. As already mentioned, the first works of both poets were published in the 1980s, as after 20 years dictatorship (1964-1984) Brazil began to open up again to democracy. Brazilian concrete poetry grew in the 1950s, when Brazil likewise transi- 
tioned from dictatorship towards democracy and engaged in a modernization process initiated by president Juscelino Kubitschek under the slogan, 50 anos em 5 ! (fifty years in five!)-Brasilia was built and the international automobile industry was installed, there was also an opening to the international arts market, and a working dialog between Brazil, Europe and the USA was established through the inauguration of the Biennale and of the Museum of Modern Arts (MASP) in São Paulo. The rapidly growing urbanization, accompanied by a mass migration from the country-side into the industrial urban centres, changed metropolitan life and with that also the point of view of the artist towards their spectator and therefore also the regard of the consumer of art.

The "partage du sensible" and a rethinking of democracy after World War II were represented in the poems of the Brazilian concretists. The means employed to reach that part of society that was confronted daily with publicity (out-doors as well as in television and the print media) and comprised both lower and middle classes included not only the visual nature of concrete poetry but also (and next to the typical structures engendered by the combination of words and syllables) the part of the poetic discourse realized in the manifestoes. The neoavant-garde of the 1950s thus initiated a dialogue with the envisioned society through the import of the language of advertising as one form of the "partage du sensible" into the aesthetic language, which itself was born within the inter-media process of concrete poetry, according to the visual arts (abstractionism) and music (dodecaphonism); a discourse that did not end with the military coup 1964. In contrast, the poets of the new generation-i.e. those, who dedicated their attention to the usage of technology to radicalize the effects of such aesthetics-pursued very different aims. After the long period of military dictatorship, during which the likes of André Vallias and Eduardo Kac grew up, their aesthetic preoccupation was much more related to an individual response to the cultural status quo than to create a new movement involving a whole group of artists, as in the 1950s. Along each individual way, they internationalized their poetic languages akin to how the concrete poets did-Vallias through co-organizing the first international exhibition on digital poetry with Friedrich W. Block in Germany in 1992; Kac joined the artist's group that was involved with new technology in Chicago in the late 1980s and became editorial member of Leonardo, one of the leading journals for experimental arts and poetry of the late $20^{\text {th }}$ and early $21^{\text {st }}$ century. It was through the universal character of their aesthetic productions that the global connections were rapidly established-but still without the quality of a movement as for the avant-gardes, but rather based on the formation of groups of key figures around the exchanges of expressions in "politics of aesthetics" through the new technologies.

\section{From Poetry to Poiesis}

The poetry corpus discussed in this essay demonstrates a technique of production based on an inter-semiotic search for creation within the visual and the conceptual (rarely complemented with auditory elements), and with its realisa- 
tion in an open media space that again reflects the preoccupation of concrete poetry with the reader: the search for a new dimension of reaching a larger group of readers outside the individual private nest and in other form than that of a simple printed book: Through interfaces, the Web, and local spaces reserved to the visual arts. Here, poems acquire the nature of art objects, and therefore the intended reader obtains the identity of an observer of a work of art sometimes planned to be exposed in a gallery or a museum or to be presented as a manifesto.

In the 1980s, Vallias left Brazil and lived in Germany for a few years. He met Vilém Flusser in Munich ${ }^{1}$ and was influenced by his investigations into artistic expression through telecommunication. Vallias" [11] first digital poems (all created with the state-of-the-art AutoCAD software for computer-aided design),produced in the 1990s are manifesto-like and emphasise the point of departure of his poetic view: the diagram, as he once explained, paraphrasing the New Testament: "no começo não era a palavra, mas sim o logaritmo" (in the beginning there was not the word, but rather the logarithm) (André Vallias, "A Crítica de Poesia", s.p.). His poem-manifesto, Nous n'avons pas compris Descartes (1997) broaches the issue of poetry making through the two faces of a diagram, by actualizing Mallarmé's emphasis on the materiality of the papersurface and also by recreating the space-word-relation established by the avantgardes, here without words, but in two diagrams: a flat one, representing the material of the surface; and one in waveform, implicating the dynamics of meanings, as if semiotic relations could be represented tri-or four-dimensionally (both diagrams are displayed incrementally and the waveform without reaching visual closure, suggesting also a development over time).

IO: Analysis follows the same idea of creating meaning by inverting the terms, also expressed by a designed diagram which shows, as a spherical surface, the "O" and, revealed by the reader's mouse click, an oblong cavity, an "invagination" of the sphere, the "I". The "I" and "O" are clearly interrelated, the "I" being formed out of the surface of the "O" and at the same time constituting the internal structure of the "O". The title of the poem suggests a representation of subjectivity that does not lead to the poet's identity anymore (cf. also Derrida's discussion of the invaginated text opening the "inside" to the "other" while denying both a stable identity in Simon M. Wortham [12], The Derrida Dictionary, pp. 76-77). The Italian word Io (English "I") is self-generated. The term "IO: Analysis" also suggests the abbreviation of "input-output analysis", a mathematic approach to modelling for understanding reciprocity of inputs and outputs in scientific models as employed in the natural sciences, engineering, and economics.

With "Prthvil" (1991), Vallias digitalized an Indian epical verse, based on its prosody. The verse of these quartets is comprised of 17 syllables, which are visu-

${ }^{1}$ In his theory of communication Flusser saw in the new media the chance that human being could have to escape from the domination of TV. Cf. after all Flussers works on communication theory and its relation to culture. Flusser testimonied, during his life in Brazil, the influence of mass-media such as TV on the popular/collective art consumption. 
alised in terms of their nature of being long or short. The structure is alternately visualised in black on white background and white on black background, the reader can gradually zoom into it, ending up with a white or black crossing of the reticular surface filling up the full screen and thereby triggering the next iteration with inverted foreground and background colours. Once again, there are no words in this metapoem, the focus remains on the representation of poetics in a digital graphical language: These first three poems exemplify Vallias' understanding of poetry as turning poiesis (making poetry) visible.

An example of the aesthetic-political point of view of concretism-the individual poet as a member of the paideuma-is given by Vallias' inter-semiotic translations. His poem Comedia (2009) could be understood as the radicalization of trans-creation in a new media-language: The poet transformed Dante's Divina Commedia into a digital movie comprising multiple synchronised streams of QR-Codes that he refers to as a "metapoem". The intertextual reference is not disclosed entirely in the poem's title, but stated in the author's upload comment. Hypo- and Hypertext are inter-related through the visual code employed, which needs to be handled by a specific machine mechanism that is easily identified (and explicitly stated in the author's upload comment, which provides a pointer to the Wikipedia page providing further background information). The human eye sees and recognizes only the kind of code in which Dante's text and related meta-information (see below) are "captured". Vallias visualises this inter-semiotic translation within a rectangular display that is subdivided into 5 square areas: four smaller quadratic areas arranged in a square on the left, and a single large quadratic area on the right. As explained in human-readable text in the first seconds of the movie (after the human-readable display of the title of the metapoem), three of the smaller squares (all but the bottom-right one, which is not used) are used to provide a complete QR-code encoded reference for the QR-encoded verse-terzina-displayed in the large square on the right: the QR-encoded (unchanging) name of the metapoem (Comedia) is displayed on the bottom left; the name of the current cantica (Inferno, Purgatorio, Paradiso) on the top left; and the canto number on the top right-note how this arrangement aptly follows the location of the position detection patterns (the three squares inset in all but the bottom-right corner of a QR code. The poet Ricardo Domeneck [13] refers, in his blog "Modo de Usar \& Co", to Vallias' metapoem as a conceptual poem in which the "making" has more relevance than the "saying": "Vallias leva ao extremo a proposta do poeta que faz, não o poeta que diz" (Vallias takes the proposing of what a poet does, not of what a poet says, to an extreme) and completes his statement by affirming that " $A$ poesia conceitual apresenta o texto como cosa mentale, não para a substituição do original dantesco (ele está todo ali), mas levando-nos à ampliação de nossa concepção do que pode ser poesia" (Conceptual poetry presents the text as cosa mentale (mind matter), not as replacement of Dante's original (which is there in its entirety), but guiding us towards extending our understanding of what poetry can be). The digital movie comes with an electro-acoustic sound track that also integrates 
medieval-style polyphonic vocal elements. This audio track complements the suggestive title of Dante's Commedia, but also is a steady reminder of the current digital form into which the Commedia was transformed, providing the reader a kind of "movie" or interactive story experience (given the required QRcode decoding).

André Vallias' Web-poem oratorio, encantação pelo rio (2007), can be interpreted as a live-presentation (registered and offered on the Web) or as an inter-active Web-poem. In the first version, the viewer combines images-projections of the words "rio/morro/logo", in different combinations-on a changing background of colours; the poet himself walks up and down in front of the screen and a voice from the off pronounces the verses which are not projected, as to complete the alternating combination of the three displayed words. The spoken words are the names of all geographical places of Rio de Janeiro, beginning with the names of the "morros" (hills) and "rios" (rivers): they form a verbal mapping of the city. The various meanings of "rio" (river, the city of Rio de Janeiro, and the conjugation of the verb "to laugh": "eu rio"/I laugh), "morro" (hill, but also: "I live/reside" or "I die") and "logo" (as logos, as adverb: "soon", or as consecutive conjunction: "therefore", etc.) in their anagrammatic combinations generate diverse views of Rio de Janeiro or of being in Rio de Janeiro. The reader participates in the poem by constructing their own verbal maps through the anagrams. Another online version of "oratorio" (available on Vallia's website) instigates the reader to interact with their mouse by selecting words that lead to others, so each the reader could, individually, re-map all of Rio de Janeiro. For example, clicking on the location names Rocinha, Corcovado or Sambódromo reveals individual references to related poems.

As designer/arranger of the location of the words, the reader follows the way Vallias utilizes this idea of design-not only in its Latin sense (also the semiotic sense), but also in the modern sense of designer languages: the combination of words with the shown diagram places the language "in-between": in terms of the inter-relation of viewer versus object, it is the viewer who decides what meaning to generate (within the given constraints).

It is not only by interacting through the interface that the reader achieves the complete meaning of the poem, but also by developing their own interpretation of the semantic combination of the significant exposed: "morro"/noun or "morro"/verb; "rio"/noun or "rio"/verb; each combined with the places and rivers cited. The well-known expression "transpiration instead of inspiration" can be seen to apply, with the viewer being forced to combine the elements of the poem so as to generate significations.

In all the poems discussed above, it is the striking preoccupation with the representation of the verbum that catches the attention of the reader, as if the verbivoco visual body of the concrete poem was transformed into its verbi logo visual material. This theme is also realized in Eduardo Kac's early visual work: the holopoems of the 1980s.

holololho (holo/eye 1983, with Fernando Catta-Preta); AbrAcAdAbrA (1984, 
with Fernando Catta-Preta); $Z_{y X}$ (1985, with Fernando Catta-Preta); Wordsl 1 and 2 (1986); Chaos (1986); and Quando? (when? 1987, with Ormeo Botelho): as suggested by all these titles, the word is shown in its fragility (of meaning and representation). Since the earliest avant-gardes, the work with the verbal materiality on the one hand reflects the poet's desire of keeping a subjective distance. and on the other hand it is through the manner in which this materiality is conceptualized that the reader recognizes the signature of its "maker". Kac seems to broach the issue of the loss of lyrical subjectivity in the aesthetic regime and inserts his lyrical self in other ways. Inter-subjectivity, a key element for understanding literature, is here suggested to be either the full and exclusive responsibility of the viewer, or to be fully materialized in the poem: holo/olho is an anagrammatic poem that reflects these two words as if they were intrinsic parts of a whole: Without holo, no olho (eye) and without olho, no holo. When in AbrAcAdAbrA the consonants orbit around the single vocal and the viewer does not have the possibility to ever get to see the whole word, it is suggested that the magic lies in the opening, through fractal views, of the mystery door to the treasure of understanding. As the three letters of the tri-dimensional axes $Z Y X$ appear and disappear across the colours of a rainbow, a mirror reflects the observer through the scene, so that they become part of the object or art. The wordsl holopoems realise complementary scenarios, where the continuous recombination of "word" and "world" revolves around the projected head of Kac himself, exposing subjectivity as physical presence of the poet, inserted in a cross-cutting of these two semantic categories. In chaos, the three-color reflection hologram generates in different rhythms the waxing and waning of the characters " $c$ ", " $h$ " and " $a$ " is opposed to the constantly shown " $s$ " and " $o$ ", creating the pattern "s.o.s": in this setting, the word holocaust can be read hypostastically. With quando?, Kac confirms Simon Biggs" [14] description of the rupture of inter-subjective communication through poetry (as an exaggeration of Ortega y Gasset's “dehumanization of art”):

Readers expect and seek the identification of an author in a text as a means to assist them in their own self differentiation. Reading a text can thus be regarded as a psycho-social act, where readers are concerned with their own constitution and differentiation, as social beings, through the treatment of the author as an avatar or equivalent symbolic deployment as imagined other (Simon Biggs, “Auto/onto-poiesis", pp. 85-86).

In quando?, the verse" A LUZ/ILUDE/ A LENTE/LENTA/MENTE" (the light illudes/tricks the lens slow-ly) can be read from right to the left, or vice-versa (slow mind the lens illudes the light), as well as in other combinations. But the words only appear in fragments, their bodies are never shown in their entirety. Gestalt Theory, according to which "the whole is more than the sum of its parts" could be called into cause here, not to approach cognition/the intellect, but to question the viewer's physical identity.

The key to Biggs" approach to his own artistic intention by explaining why he chooses the self-generated digital poem over the self-created, human articulated meanings, lies in the following statement: 
In seeking to disturb the manner in which we see things, and thus our accepted notion of self as constructed through seeing, the objective is to destabilise our sense of self. [...] In the absence of a writer or intended meaning all the reader has available is the option to contemplate their own act of reading (Simon Biggs, “Auto/onto-poiesis”, pp. 86).

With the fractal exposure of letters and partial words, Eduardo Kac [15] also plays with the viewer's perception and with their identity as a poem's reader:

As distinguished from visual poetry, it seeks to express the discontinuity of thought; in other words, the perception of a holopoem takes place neither linearly nor simultaneously but rather through fragments seen at random by the observer, depending on the observer's position relative to the poem. Perception in space of colors, volumes, degrees of transparency changes in form, relative positions of letters and words, and the appearance and disappearance of forms is inseparable from the syntactic and semantic perception of the text. Color is not simply color; it has poetic functions as well: A letter is not just a letter but also a pictorial shape (Eduardo Kac and Ormeo Botelho, "Holopoetry", 397).

Among the many transgenic works by Eduardo Kac there are three in which the relation between the representation of the self and the reader is radicalized to new forms of arts perception: Genesis (1999), GFP Bunny (2000) and Cypher (2009). As the genre's name suggests, this kind of work emphasizes a physical identity that is related to words in novel contexts and through which the reader is required to perceive and interact with the object in a new manner. In Genesis, Kac developed the "artist's gene", created in a laboratory by infiltrating an artificial gene with the words of the Old Testament, "Let man have dominion over the fish of the sea, and over the fowl of the air, and over every living thing that moves upon the earth" (Genesis I, 28), which were first transformed into Morse code and subsequently into a DNA sequence, according to a mapping to nucleic acids developed by Kac especially for this piece. The traces of the Morse code are represented by Thymine, the periods by Cytosine and Adenine, and the spaces between the letters by Guanine ${ }^{2}$. The strand of DNA thus created forms, in its genetic code, the alphabet of the piece, Genesis.

In GFP-Bunny, the fluorescent green protein-rabbit named Alba was created in a laboratory under the advice and supervision of Kac. When exposed to blue light, Alba lights up in green colour. On his website, Kac provides an extensive treatise of the meaning of this "act" of creating a new species that starts with a digression about the different stances towards the rabbit in different cultures over global history and relating these to his concept of trans-genics. This led him in turn to linking his transgenic work to the key notions of ethics; art; religion; family; media; science; and nature. Accordingly, GFP-Bunny expresses not only an aesthetic will, but is also taken to communicate and question themes such as: ethics in genetics; the family as the social nucleus that protects its members; religion versus human beings practicing the act of creation of new species; art as

${ }^{2}$ The technical explanations of each piece of work are kindly provided by Eduardo Kac on his Web-Site. 
part of the artist's intentions; the achievements of science and its reflection on other disciplines and on society; and the possibilities of human intervention on nature.

Most recently, Kac [16] created Cypher, which takes the form of an open book-an art book without pages-that offers a work set for anyone interested in producing transgenic poetry. This transgenic kit contains the necessary tools, such as Petri dishes; streaking loops; and pipettes, as well as a modified genetic code created for this set. The mini-laboratory is "to place in the hands of the viewer the decision and the power to literally give life to the artwork" (Eduardo Kac on Cypher (2009), http://www.ekac.org/cypher.text.html).

Our selection of works by André Vallias and Eduardo Kac used to discuss the work of art within modernity as well as in its aesthetic politics is also meant to show how subjectivity is dissolved as a consequence of the adoption of new media: through the disappearance of an intended self in poetry, it looses its verbal connection to the materialized word, the expression of meanings and its representation. The well-known inter-subjectivity of the lyric discourse is lost; the word-or that which evocates words and therefore meanings-is now much more linked to the procedures for its appearance, and the interpretation depends on the perception of this appearance, through diagrams; holograms; genetic codes; and, finally, as a recipe how to create new self-generating poems. The magic in understanding the arts is altered; the created illusion evokes a different "aesthetic misunderstanding".

\section{Misunderstanding Categories of Art-Reception}

One of the distinguishing achievements of the procedures of the avant-gardes was the separation of semiotic signs of meaning from their representation, isolating meaning from the material of its representation and, conversely, disrupting the ties between the material and its representational and other uses. Sign categories were recombined, or simply associated individually to semantic categories leaving it up to the reception to select out of their own repertoire of semiotic signs a combination deemed appropriate to understand the aesthetical meaning of the object of art.

This procedure is however not exclusive to the avant-gardes: it already appears in the German Romantic, where instrumental accompaniment was separated from vocal music, providing a much higher semantic category: to explain the un-explicable. Thus, this procedure, as also employed by Kac and Vallias, cannot be taken as necessarily a legacy of the avant-gardes, but rather can be viewed within Rancière's "régime esthétique" as a "partage du sensible" within the adaptation of poetic meanings by technological communication in a given society. For Rancière [1], the identification of the written arts is compared to the regime of society in its proportional distributions, in its "distribution of the sensible", creating the aesthetic regime of the literary misunderstanding ("le malentendu littéraire").

Applying this (mis) understanding in the readings of the aesthetic manifesta- 
tion by Vallias and Kac may disclose answers beyond the readable, the visible and the audible. We could affirm, with Rancière's Politique de la Littérature, that it is

[...] un mode d'articulation entre des manières de faire, des formes de visibilité de ces manières de faire et de modes de pensabilité de leurs rapports ... c'est au niveau du découpage sensible du commun de la communauté, des formes de sa visibilité et de son aménagement, que se pose la question du rapport esthétique/politique (Rancière, Le Partage, p. 10, pp. 24-25).

In relation to Peter Bürger's [17] view of the avant-gardes, Rancière's "politics of aesthetics" is much more generous in its space of articulation. Bürger seems much more preoccupied with disclaiming the existence of the avant-gardes by refusing to recognize a special status for the political discourse of the first avant-garde:

Die Wiederaufnahme der avantgardistischen Intentionen mit den Mitteln des Avantgardismus kann in einem veränderten Kontext nicht einmal mehr die begrenzte Wirkung der historischen Avantgarden erreichen. Insofern die Mittel, mit deren Hilfe die Avantgardisten die Aufhebung der Kunst zu bewirken hofften, inzwischen Kunstwerkstatus erlangt haben (Peter Bürger, Theorie der Avantgarde, p. 80).

But also Hall Foster [18], who in contrast to Bürger even identified a third avant-garde (i.e. a second distinct phase of the neo-avant-garde), which he placed in the 1960s, never dissociated "the politics of aesthetics" from its own representation:

As the first neo-avant-garde recovers the historical avant-garde, Dada in particular, it does so often literally, through a reprise of its basic devices, the effect of which is less to transform the institution of art than to transform the avant-garde into an institution (Hal Foster, The Return of the Real, p. 21).

Applying these considerations to the discussion of the aesthetic production of Kac and Vallias would mean to further the dialog between arrière- and avantgarde, and thereby to subscribe to a continued application of avant-gardistic politics to their works; re-thinking those objects in Rancière's context of "mésentente" and "malentendu", on the other hand, should open up a much larger "jeu libre" for interpretation.

\section{Mésentente and Malentendu: The Politics of Art Reception}

In Politique de la Littérature [19] [20], Rancière combines his "partage du sensible" with politics of literature as follows:

L'activité politique [...] introduit sur la scène du commun des objets e des sujets nouveaux. Elle rend visible ce qui était invisible, elle rend audibles comme êtres parlants ceux qui n'étaient entendus que comme animaux bruyants (Jacques Rancière, Politique, p. 12).

About his concepts of mésentente and malentendu he writes:

Mésentente et malentendu peuvent être ramenés à une figure commune, celle du dissensus, c'est-à-dire de la rupture d'une harmonie entre le sensible et le 
sens, entre le compte des corps et celui des significations. Le dissensus, c'est la reconfiguration des rapports entre sens et sens, c'est-à-dire entre présence sensible et signification (Jacques Rancière, "Politique de la Littérature", s.p.).

Rancière [2] derived the malentenduas a reversal of his concept of mésentente: the malentendu searches for a perfect unity of thing, idea and representation that the value of the original concept, free of any kind of Mannerism, should correspond to in its totality. The literary "malentendu" thus exists in the recreation of unique concepts that as they are function only in the context in which they have been created. This can be taken to be a reason for the persistence of the tendency of reading bio-poetry as a consequence of the avantgardes. And that is why the "partage du sensible" should be interpreted in a strong relation to the intended reader of Ortega y Gasset's modernity.

The paideuma created by the Brazilian concrete poets as their "aesthetic régime" provides the reception with a simplified way to interpret their own "politics of aesthetics". If we want to understand the individual aesthetic communications of Vallias and Kac, we should, therefore, eliminate the legacy umbilical cord which could all too easily be built through the understanding of structures and inter-semiotic combinations.

La notion de modernité voudrait qu'il y ait un sens unique alors que la temporalité propre du régime esthétique des arts est celle d'une co-présence de temporalités hétérogènes. Elle constitue donc une volonté et une manière d'interpréter internes au régime esthétique qui y jouent un rôle très important mais qui sont évidemment totalement inadéquats pour le définir et plus encore pour marquer le lien entre esthétique et politique (Rancière, "Le Partage", s.p.).

When we de-contextualize the art object from its aesthetic-political function, we operate in the same way as the avant-gardes: we separate the part from the whole by emphasising one semiotic aspect and turning back to the whole within the interpretation process. This reading should also work for the poems of Kac and Vallias, and may allow us to obtain more substantial feedback: the poetry making of the two poets here discussed here should be read in a manner comparable to the attributes granted to one of the fathers of avant-gardistic writings, Stephan Mallarmé, where the critics avoided to try to find a meaningful syntax and where the combination of the visual, structural and audible suggests a new semantics on the surface.

A review of the classic rhetoric as a methodical tool for the reading of avantgarde texts reveals the following principal standards:

- Historical avant-garde: emphasis on the elocutio.

- Neo-avant-garde: emphasis on an egalitarian distribution of the elocutio, so as to suggest a decodification in the way of the Gestalt-Theory.

- Post-neo-avant-garde: redistribution of the elocutio, to raise awareness of the perception process during the reading. This perception can be fragmented and creates the illusion of the natural convention of human vision/audition.

The last item $\mathrm{f}$ this list is relevant for the readings of the corpus considered here, if Ortega \& Gasset's "identification regime" is adopted and "politics of 
aesthetics" thus remains outside of analytical scope. The poetic creation, viewed through the lens of the observer seeking the inter-subjective dialog with the author-or, in other words, who wants to understand their own poetic "Empfinden"-finds its communications link through the exaggeration of one of its semiotic representation items. This kind of reading, focused on the part in order to understand the whole, is an interpretation method linked to the reading methods of the avant-gardes. This thin line, which can be followed with Ortega \& Gasset's modernity concepts, can be combined with the reading proposals of the authors, and this compromise be objectified with the help of Rancière's "mésentente" and "malentendu" [2]: In this way, linking the manipulation of the elocutio and these concepts would offer a surface for poetic understanding of the works by Kac and Vallias and probably others.

Mésentente et malentendu peuvent être ramenés à une figure commune, celle du dissensus, c'est-à-dire de la rupture d'une harmonie entre le sensible et le sens, entre le compte des corps et celui des significations. Le dissensus, c'est la reconfiguration des rapports entre sens et sens, c'est-à-dire entre présence sensible et signification (Rancière, "Le Partage", s.p.).

The "partage du sensible" could thus be discussed in its distribution within the object of art, as an existence between the poem and its observer. If on the one hand we have a paradigm change in the inter-subjective language of poetry by Ortega \& Gasset, we have on the other the complete elimination of the author by post-modern critics like Roland Barthes and Jacques Derrida and, as seen in self-generated digital poetry, the extinction of the author as generator of meanings itself. Rancière discusses Latin-American modernity; based on Jorge Luis Borges, he combines the collective power of imagination of the reader with the imaginary power of, for example, the fairy-tales. The purest form of the partage $d u$ sensible should be the one in which no excesses are found, in which form and content are covered exactly. Brazilian concrete poetry adopted this model (as the structuralists did before), forcing the signifiant to be the focus of interpretation and bringing the combination of collective imagination of the reader and imaginary potential of the poem to a neutral position. What happens in practice is that the imagination of the reader is instigated to project many more signifiés than the poem contains. There is no equilibrium between poem and receptionthe poem requires much more activity of the passive reader, so that it becomes almost part of the "jeu libre" of the "partage du sensible". Post-concrete poems like those discussed here do not have the intrinsic power of imagination, but the intrinsic power to unsettle perception, physical perception (visual in most cases), so that the sense of the interpretation will activate another "compartment" of our imagination. The power of imagination is transferred completely to the reaction of the reader in its identity. It is not any more the intellectual capability but the cognitive one, which does not reach the passive understanding of a given poem anymore but rather the creative identity of the reader.

Following the thin line from Romanticism to Modernity by Ortega \& Gasset, we ascertain a gradual disappearing of the lyricalself. Concrete poetry dissolved 
the concrete self into a collective production. The poems analyzed here transfer the poem's self into the machine by substituting the word base by the algorithm or by transferring the creation process to other "entities" such as plants; DNA strands; light; and the active-observer/reader. Here, the hybridity of a poem is present not only in its structure but also in the interfering of a reader's group or the individual reader. In terms of "politics of aesthetics" the Brazilian concrete poets created the collective self as an intended projection of the readers group; the annulment of the self in the poems could then be a projection of the destruction of the collective imaginary intended by the Brazilian mass-media of the 1970s and 1980s. When fairytales wear the perfect combination of imagination (perception) and imaginary (intended perception) - as the telenovel as always do-this radicalized form of non-identification models is a response to the massification of the imaginary, getting the reader/observer to re-think their perception and understanding of arts: from the emotional, through the intellectual, to the physical "understanding". All these categories manipulate the reader in their identity. For Plato, illusion was the highest achievement of the arts; for poets like Vallias and Kac, it is the creation of a new identity in the spectator reading process.

\section{Conclusions}

The poems discussed do not have the pretention to be captured as wholes through their parts-like the poems of the neo-avant-garde. It is by claiming the

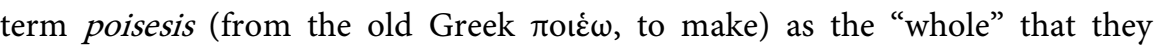
separate their understanding of art from their predecessors. Regarding poiesis as "politics of aesthetics" within the "aesthetic régime", this corpus reveals itself as a critical claiming act of Modernity. The power of fiction, and here the power of interpretation, lie in the reader and not in the work of art. Fictional work, widespread through mass-media, can easily enclose the imagination of the reader in its imaginary settings as a whole; in poiesis, this self-image of the reader is excluded. The imaginary interaction between the work of fiction and the reader is not intended here, but matized. The power of the mass-media in the retention of collective imagination became evident towards the end of the Brazilian dictatorship at the beginning of the 1980s and, with the new democratic regime, should be re-thought: not the work of fiction itself, but the mass-media is responsible for keeping the readers' imagination captured.

This denouncement is made by these poets through the media of the massestelevision and the Web and through the literary genre, in which no fiction is to be found in poetry.

When the transition from lyrical inter-subjectivity to a trans-collective authorship occurs by the avant-gardes, we observe, in post-modern texts, a nearly complete dissolution of the inherent authorship in the works of art. The dislocation of the authorship from poetical subjectivity to the collective reception in the process of interpretation includes the "reader" in the creation process, in the "poetry making". The author appears as fulfilling the function of vehicle of the 
poetic representation. To suspend the inter-subjective communication of the art object, the poetic "Empfinden" of the reader, which is based on emotional or intellectual identification with the poetry maker through the understanding of the work of art, also disappears, reduced to the perception of the object. But is this really a reduction?

What are the consequences of an aesthetic régime that embraces a kind of politics of aesthetics that does not represent, through the art object, the structures of a given genre any more, but instead seeks, through the dissolution of the genre, the end of it?

When the artist dislocates themselves from their object of art, and this object has its "own life", they are acting much more as a creator than as an author. There are no more manifests accompanying the piece, and the manifestations come from the spectator (GFP-Bunny triggered a flood of emails leading to the freeing of the rabbit and thus to the reproduction of the species).

Creators explain their poetry making, but not its intention; they explain how the reader has to read/observe the object of art or also interact with it, so that they can be part of the creation (Kac's Cypher and Vallias' Comedia) or learn to interact using and projecting its own sign-repertoire through self-created associations by interacting with the given signs (Kac's GFP-Bunny and Vallias' oratorio).

The authorial "partage du sensible", the artificial dissolution of what the author represents as lyrical self, or critical self: the creator of GFP-Bunny becomes a citizen, promenading through Avignon during the Festival, carrying his rabbit.

The poet who creates objects of art through words set in DNA or QR-Code is the carrier of a given identity that is not anymore the abstract one, which we associate to the intended author. The poet, as part of a social regime, is at the same time and without any changes also part of the aesthetic regime.

\section{References}

[1] Rancière, J. (2000) Le Partage du Sensible. La Fabrique, Paris.

[2] Rancière, J. (2007) Le Partage du Sensible/La Fabrique du Sensible. Multitudes. Revue politique, artistique, philosophique. http://multitudes.samizdat.net/Le-partage-du-sensible

[3] José Ortega y Gasset (1956) The Dehumanization of Art and Other Writings on Art and Culture. Double Day \& Co., New York.

[4] Vallias, A. (2014) Concrete Poems: In his Blog. Digital Poems: in His Website, and on YouTube.

http://andrevallias.tumblr.com/post/72548683265/amerindio-andre-vallias-2014 http://www.andrevallias.com/ http://www.youtube.com/user/vallias

[5] Eduardo Kac. (All Poems and Works of Art Discussed on This Paper Are Available On-Line on the Official Websites, Blogs and YouTube of the Authors) http://www.ekac.org/

[6] Perrone, C. (2008) Versatile Vanguard Vectors: From Visible Voices to Virtual Vortices in the Vamps, Versions, and Voyages of Brazilian Concrete Poetry. Graphos, 10, 69-87. 
[7] de Campos, A., Pignatari, D. and de Campos, H. (2006) Teoria da Poesia Concreta. Textos críticos e manifestos 1950-1960. 4th Edition, Ateliê Editorial, Cotia.

[8] Drucker, J. and Kac, E. (1997) Digital Reflections: The Dialogue of Art and Technology. Art Journal, 56, 18-19.

[9] Pedrosa, M. (1951) The Chromatic Plastic Dynamism of Abraham Palatnik: An Introduction to the First International Biennial of São Paulo. Translated from the Portuguese by Eduardo Kac, Leonardo Online. A Radical Intervention: Brazilian Electronic Art. http://www.leonardo.info/isast/spec.projects/pedrosa.html

[10] Marx, W. (2008) Les arrière-gardes au XXe siècle. Quadrige, Paris.

[11] Vallias, A. (2011) A Crítica de Poesia em Tempos Digitais. Conexões Itaú Cultural. http://conexoesitaucultural.org.br/critica-literaria/3670/

[12] Wortham, S.M. (2010) The Derrida Dictionary. Continuum, London, 76-77.

[13] Domeneck, R. and Vallias, A. (2011) In: Modo de Usar \& Co., (Blog) Ed., Ricardo Domeneck, Angélica Freitas and Marília Garcia, article on André Vallias published on 4 April. http://revistamododeusar.blogspot.co.at/2011/04/andre-vallias.html

[14] Biggs, S. (2008) Auto/onto-Poiesis. In: Vallias, A., Block, F.W. and Navas, A.M., Eds., Poiesis. Poesia entre Pixel e Programa Exhibition catalogue, Oi Futuro, Rio de Janeiro, 83-85.

[15] Kac, E. and Botelho, O. (1989) Holopoetry and Fractal Holopoetry: Digital Holography as an Art Medium. Leonardo, 22, 397-402. https://doi.org/10.2307/1575403

[16] Kac, E. (2009) Cypher, a Diy Transgenic Kit. http://www.ekac.org/cypher.text.html

[17] Bürger, P. (1974) Theorie der Avantgarde. Suhrkamp, Frankfurt Main.

[18] Foster, H. (1996) The Return of the Real. The Avant-Garde at the End of the Century. MIT, Cambridge.

[19] Rancière, J. (2007) Politique de la Littérature. Galilée, Paris.

[20] Rancière, J. (2007) Politique de la Littérature, Interview with Ruffel, L., Vox Poetica, Lettres et sciences humaines.

http://www.vox-poetica.org/entretiens/intRanciere.html

Submit or recommend next manuscript to OALib Journal and we will provide best service for you:

- Publication frequency: Monthly

- 9 subject areas of science, technology and medicine

- Fair and rigorous peer-review system

- Fast publication process

- Article promotion in various social networking sites (LinkedIn, Facebook, Twitter, etc.)

- Maximum dissemination of your research work

Submit Your Paper Online: Click Here to Submit

Or Contact service@oalib.com 